\title{
Relevance Between the Degree of Industrial Competition and Fair Value Information: Study on the Listed Companies in China
}

\author{
Xuemin Zhuang, Yonggen Luo \\ Guangdong University of Finance and Economics (China) \\ jnuacc2002@163.com, stanley2002@sina.com
}

Received: May 2015

Accepted: June 2015

\section{Abstract:}

Purpose: The purpose of this article is to study whether there exists natural relationship between fair value and corporate external market. A series of special phenomenon in the application of fair value arouses our research interests, which present evidences on how competition affects the correlation of fair value information.

Design/methodology/approach: this thesis chooses fair value changes gains and losses and calculate the ratio of DFVPSit as the alternative variable of the fair value. In order to effectively inspect the mutual influence between the degree of industry competition and the value relevance of fair value, and reduce the impact of multi-collinearity, we built a regression model on the hypothesis, which supposes that if other conditions are the same, the fair value information has greater value relevance if the degree of the industry competition is greater. To test the hypothesis, we use the comparison of the DFVPSit coefficient absolute value to judge the value relevance of fair value information, and the greater the absolute value is, the higher relevance between the changes in fair value per share profits and losses with the stock prices.

Findings: The higher the degree of competition in the industry is, the more fair value information relevance is. Also, there are evidences representing that fair value information often presents negative correlation with the stock price. 
Originality/value: The main contribution of the article is to show that not only need we make the formulation and implementation of the high quality of fair value accounting standards to suit for both the national conditions and international practice, but also need we further to improve the company's external governance mechanism to promote fair value's information correlation.

Keywords: fair value information quality, value relevance, industry competition

\section{Introduction}

According to the efficient market theory, the degree of market's effectiveness is influenced by the information disclosure level, which is an important motivation of accounting profession trying to promote it. In October 2010, American Financial Accounting Standards Board (FASB) and the International Accounting Standards Board (IASB) issued a formal announcement "Conceptual Framework for Financial Reporting: The Objective of General Purpose Financial Reporting and Qualitative Characteristics of Useful Financial Information". At the same time, FASB served it as the eighth announcement of financial accounting concepts statement (SFAC No. 8). In SFAC No.8, correlation and Faithfulness are the most basic characteristics of the quality of accounting information. Faithfulness replaced reliability and it means that "the financial information faithfully represents the economic phenomenon which is intended to be reflected ". The definition of correlation is the same as the SFAC No.2, which says "the relevant financial information is that can influence decision makers". A typical example is that investors need information for securities pricing. Different market environment would cause different degree of severity of moral hazard induced by the agent relationship (Francis, Khurana \& Pereira, 2003), which may lead to different costs of information searching. Generally speaking, the person who pays more for searching information to get high quality and quantity of information will be in a relatively dominant position, which also determines the differences of stock quotation by different investors. From above all, we can consider the problem that whether the fair value accounting information disclosure can decrease the investors' searching costs caused by the differences of the market environment, which further makes the stock pricing is more reasonable. That is to say, whether the fair value information relevance?

Although most of the empirical evidence shows that the fair value information does have value relevance effects (Barth, Landsman \& Wahlen, 1995; Nelson, 1996), however, the global financial crisis triggered by the American subprime mortgage again attracted a heavy debate about the fair value measurement (Huang, 2009). Some people dispute that fair value has strong correlation reflection, while other people think that this is the clear evidence of the flaws of fair value measurement in a special market of financial crisis, such as the strong subjective judgment of fair value measurement attribute and pro-cyclical effect. Sharp 
fluctuations caused by financial crisis makes the problem of whether the accounting information measured by fair value has better value relevance become more urgent and important in the different environment or industry competition environment.

Previous research on relationship between corporate governance and accounting information quality are mostly viewed from the perspective of internal corporate governance mechanism. Actually there exists natural relationship between fair value and corporate external market. A series of special phenomenon in the application of fair value arouses our research interests, which combines company external factor to research these phenomenon. Based on the considerations, our paper presents evidence on how competition affects the correlation of fair value information. We find that the higher degree of industrial competition, the more value relevance about fair value information; and fair value information often presents negative correlation with the stock price. A possible explanation is that because of the impact of the financial crisis, the pro-cyclical effects of fair value makes investors understanding wrong; they may think that the firm whose financial statement uses more fair value information will be in higher risk and that will affect the investment decision. This study argues that the value relevance of fair value information is vulnerable to the impact of the industry. At the present stage of China, company's external governance mechanism should be improved so as to guarantee the fair value accounting information to exert its decision usefulness.

The thesis is arranged as follows: after the introduction, the next part is the literature review; the following part is the theoretical analysis then the research hypothesis; the fourth part is the variable measurement and model selection; the fifth part is the analysis of statistical and empirical descriptive results; the final part is the conclusion of the study.

\section{Literature Review}

Judging from the related literature for the research about the correlation of the fair value and the relationship with the market, there was a greater difference between those before and after the financial crisis. Before the financial crisis, the researches on the relationship between the fair value and the market environment were few (Huang, 2009), which mainly focused on the normative research of the fair value measurement attributes and the empirical research of the fair value and decision usefulness. Barth's research (Barth, 2004) pointed out that, the use of fair value had intensified the volatility of financial statements. The volatility has three sources: the estimation error volatility, the inherent volatility and the mixed-measurement volatility. With increasing the use of fair value, it can reduce the volatility of the mixed measurement, but increase the volatility of estimation error. As for the inherent volatility, the financial reports transmit the information to market participants, which was conducive to the stability of the financial markets. Guillaume (2009) studied the "loop feedback channel effect" of fair value, and they thought that the accounting information was relevant in the imperfect 
market. When the market rises, the fair value measurement amplify assets rising caused by market environmental factors, which results in excessive upward reaction of the stock market, and thus foams are formed. And when the market fell, the fair value would magnify the effect of falling asset prices, which causes stock market excessive downward reaction, and it can cause systemic risk in extreme cases. In contrast, the European Central Bank (ECB, 2004) pointed out in the study of "fair value accounting and financial stability" that expanding the scope of application of the fair value would aggravate the volatility of the bank balance sheets, and may reduce the bank response capacity under the adverse economic environment. More seriously, in the case of expanding the application range of fair value and implementing the new Basel Capital Accord, it would develop the pro-cyclical effect of bank credit policy.

After the financial crisis, more related researches appeared, and they were more based on the relationship between fair value and market volatility (Wang, sun \& Li, 2009). Guillaume, Sapra and Shin (2008) analyzed the pros and cons of historical cost and mark-to-market. They found that due to ignoring the price signals, the historical cost was invalid on the information reflection, although the mark-to-market was effective on the information reflection, which increased interfering factors unrelated to fundamentals on the information content of the current market price, thus exacerbated the volatility of market price. At the same time, Guillaume's another study (Guillaume et al., 2008) thought that fair value accelerated the price decline during the recession stage of market, and increased the potential systemic risks. Boyer (2007) investigated the effect of the fair value to the financial crisis. The research shows that fair value accounting reform usually assumes to provide better accounting information on the company's financial situation for the stakeholders, so increasing the level of disclosure of information can enhance the flexibility of economy and prevent a serious economic crisis. However, permanent differences caused by the fair value increase the future uncertain degree, the risk of financial institutions have more pro-cyclical effect, so as to make the financial system more fragile. Allen and Carletti (2008), Wallison (2008) all considered that fair value accounting was likely to cause irrational falling of asset prices, generating asset bubble, with a distinct pro-cyclical effects. The researches of Khan (2008), Barth and Taylor (2010) thought that fair value disclosure level would affect the investors assessing the value of bank's assets, liabilities and risk, which increase the influence degree of the subprime mortgage crisis and the spread of financial crisis. It causes a vicious cycle of asset prices spiral down. Laux and Leuz (2009) considered that fair value accounting was associated markedly with high valuation of bank assets, but there was nothing to do with the downward spiral in asset prices.

Related literature about the research on the relationship between fair value and market in China was relatively rare and the most of them were normative research. Huang (2009) studied normatively the mechanism of the fair value accounting pro-cyclical response facilitation effect and the transmission mechanism. He thought that the design of accounting standards had significant flaw in the unstable environment, which may lead transaction accounts and bank accounts to unpredictable pro-cyclical effects. And it is pointed out that the 
fair value accounting conducting pro-cyclical effect was mainly through three kinds of mechanisms, which were capital supervision, risk management and the psychological reaction. Ge (2009) believed that the financial crisis was rooted in the lack of US financial regulation and excessive speculation in derivatives. The fair value is useful, and the contagion effect of the crisis is limited in China. Through empirical research on panel data of A-share market in China $\mathrm{Hu}$ and Liu (2012) found that the fair value gains reduced market volatility.

From the literature review, we find that more and more articles focus on the relation between fair value and market research. However, in the related aspects of the empirical studies are less. Under the special national conditions in China, the researches about the relation between fair value and market are fewer, and the researches from the perspective of industry competition degree to study the relationship between the fair value and the market are most zero. Therefore, in this paper, we try to make an empirical research from the perspective of the influence of industry competition degree on the value relevance of fair value information.

\section{Theoretical Analysis and Hypothesis Development}

Bushman and Smith thought that the purpose of the corporate control mechanism was mainly to make managers activities more in line with the interests of shareholders. Corporate control mechanism includes internal and external mechanism, and the external mechanism such as corporate control market, product competition market and labor market, and so on. Hong Yan Kang thought that one of the goals of the governance study on the accounting was to ease agency problems caused by managers and external market separation. There are significant differences in the different regions of China, both on the regional market level and the degree of competition in the industry, which are the company's important external mechanisms. As an important part of accounting research, the fair value accounting must help ease the agency problem caused by the regional differences.

SFAC No.8 establishes the financial reporting objective outlook, which is dominated by decision-making useful concept. China issued "accounting standard for business enterprises" in 2006, in which the use of the fair value is strengthened. The fair value accounting is closely connected with the decision-making useful concept, which is helpful to improve the value relevance of accounting information quality. Because the difference of competition between different industries in China is more obvious, such as electronic industry and manufacturing products with high degree of competition, while the electric power industry and oil industry presenting industry monopoly, the product competition is significantly lower. Thus as an important part of the investment decision, the quality of accounting information of companies will be affected by the degree of industry. Some literatures have focused on industry competition and the quality of accounting information. In recent years, such as Li (2011), Yuan (2013),they focused their research on the industry competition and the quality of accounting 
information and accounting conservatism, and found that a high degree of industry competition can effectively improve the quality of accounting information. In addition, as Haixia (2011), Wang (2012), they started research on the investor protection and industry competition, and they found that the higher degree of industry competition can promote the enterprise value and increase the level of information disclosure.

Beyond Property-Right Argument proposed by Martin and Parker (1997) and other scholars thought that property rights arrangement will not necessarily improve enterprise performance, and only market competition is the fundamental guarantee of enterprise performance improvement. The Beyond Property-Right Argument emphasizes the common role of competition and corporate governance on enterprise management. According to the Beyond Property-Right Argument, if the enterprise would like to improve the corporate governance mechanism, the basic motivation is to introduce competition. As an important part of corporate governance mechanism, accounting information disclosure quality is inevitably affected by the degree of competition in the industry. In addition, the more intense competition in the industry, the more intense fighting on a variety of resources, in order to grab the limited resources, the company has to reduce the information asymmetry factors so as to reduce investor's uncertainties. Disclosing more accounting information, and improving the quality of accounting information, both are effective means. The fair value can reflect timely the change of market value of assets and liabilities, the gains and losses. Because of market changing, it also can reflect the financial situation of enterprises and financial risk more accurately, so as to improve the decision usefulness of the information. The information disclosure of the fair value is more conducive to investors in investment decisions at this time, namely the fair value information has value relevance. On the contrary, in the industry of a low degree of competition, because they can more easily get monopoly rents, companies need not to disclose more accounting information to enhance the company value of obtaining the favor of investors, and in the monopoly industry, investors will pay more attention to the size of corporate monopoly degree rather than the quality of information disclosure. Therefore, this paper put forward a hypothesis:

$\mathrm{H}$ : If other conditions are the same, the fair value information has greater value relevance if the degree of the industry competition is greater.

\section{Measurement of Variables and Methodology}

\subsection{Variable Measure}

Measure of the degree of industry competition. Zhong and Fan (2004) use the rate of return on net assets mean and standard deviation as a measure to determine the degree of product market competition, and the results show that the market competition degree of mining, 
electricity, gas, water, transportation and warehousing industry is low, while the market competition of machinery, equipment, instruments, real estate, textile and garment fur, food the beverage, the information technology industry achieve to a higher degree. This paper uses the same method, with the rate of return on net assets as the basis of judgment, and the "China Securities Regulatory Commission listing Corporation Industry Classification guide" as the industry division basis, on China's stock market data from 2007 to 2011 (due to the financial and insurance industry has its own particularity, therefore that are not included in the this study) to identify the degree of competition of stock market level in China. If whole average of the rate of return on net assets is higher, but overall standard deviation is lower, which indicates the degree of product market competition is low, the opposite is higher.

In Table 1, according to the "Chinese CSRC listing Corporation industry classification guidelines", A is the agriculture, forest, animal husbandry, fishery, B is the mining industry, C is the manufacturing, $\mathrm{D}$ is the electric power, gas and water production and supply industry, $\mathrm{E}$ is the construction industry, $F$ is transport, warehousing and storage, $G$ is the information technology industry, $\mathrm{H}$ is the wholesale and retail trade, $\mathrm{J}$ is the real estate industry, $\mathrm{K}$ is the social service, $L$ is the communication and culture industry, $M$ is for synthesis.

\begin{tabular}{|l|c|c|c|c|c|c|c|c|c|c|c|c|}
\hline Sector & A & B & C & D & E & F & G & H & J & K & L & M \\
\hline Count & 213 & 195 & 5543 & 329 & 195 & 340 & 693 & 514 & 427 & 278 & 84 & 341 \\
\hline Average & -2.17 & 17.67 & 2.98 & 4.49 & 8.71 & 9.11 & 8.32 & 12.75 & 10.57 & 6.67 & 7.37 & 7.75 \\
\hline Variance & 50.28 & 11.47 & 214.9 & 22.57 & 14.64 & 12.49 & 39.48 & 46.62 & 11.43 & 37.86 & 19.33 & 25.6 \\
\hline
\end{tabular}

Table 1. All sectors of net assets yield comparison table

As the results in Table 1 , the overall mean of B mining industry, $\mathrm{J}$ the real estate industry, $\mathrm{F}$ the transport and warehousing, $\mathrm{E}$ the construction is $8 \%-18 \%$, at a high level, the overall standard deviation is $10 \%-15 \%$, the overall is relatively stable, and therefore it can be classified into the lower degree of industry competition. The overall mean of A agriculture, forest, animal husbandry, fishery, manufacturing, $\mathrm{K}$ social services is $-2 \%-7 \%$, at a low level, while the overall standard deviation is $35 \%$ above, the general is not stable, which may be attributed to the higher degree of industry competition. Returns in other industries are in the medium level, the degree of stability is in general too. Different market competition degree has close relationship with product market competition environment in China. The threshold of mining industry is higher and the requirements for the objective of resources are higher, so the degree of competition is low relatively, the income is high and stable relatively; while in transportation and warehousing industry and the construction industry with a certain monopoly, so the degree of competition is relatively low; the real estate industry has a higher income, it will attract the influx of funds, but due to relatively strong financial support and for a longer time, what's more, the national macroeconomic situation is not conducive to the 
development of real estate industry and the government sets limitations to it, so the market competition degree is low relatively. While the situation of agriculture, forestry, animal husbandry and fishery is good, may be due to inflation and other reasons, the industry's prices is increasingly high, thus attract more and more enterprises to enter, leading to increase the degree of competition; There are many different kinds of manufacturing products, which are easy to imitate and the replacement of product is fast, which leads to fierce competition in the market; the overall income of social services is low, and is closely related to the nature of the industry, but in recent years the entire industry is in a downturn situation, which may lead to more access to services and consulting industry, leading to the degree of competition in the industry growing.

\subsection{Model Selection}

The pricing model and return model are the most commonly used for financial data and corporate value relevance research. Return model as the traditional method has been widely applied, but the problem is that the explanation capacity of accounting earnings is often low. For example, Ohlson's price model (Feltham \& Ohlson, 1995) is used fully in many studies about the value relevance of accounting information. Kothari and Zimmerman (1995) have put forward the price model, which has a better accounting information in the economic explanation ability. Therefore, this paper uses price model.

Considerable part of the China accounting standards issued in 2006 use the fair value, including "intends to fair value measurement mode of investment real estate", "measured by fair value and their changes into the current profits and losses of financial assets and available for sale financial assets", "measured by fair value and the profits and losses of the change in the current period calculated into financial liabilities" and "financial derivatives". And the above fair value information can not be effectively measured through the annual report, so this thesis chooses the accounting subject of fair value changes gains and losses which belongs to income statement and calculate the ratio of DFVPS ${ }_{i t}$ as the alternative variable of the fair value. Lu (2008) also uses a similar approach when she tested the effect of the standard of using fair value.

According to the classification of the degree of industry competition, in order to effectively inspect the mutual influence between the degree of industry competition and the value relevance of fair value, and reduce the impact of multi-collinearity, we built the following regression model on the hypothesis:

$$
P_{i t}=\beta_{0}+\beta_{1} \bullet B V_{i t}+\beta_{2} \bullet E_{i t}+\beta_{3} \bullet D F V P S_{i t}+\varepsilon_{i t}
$$


the model (1) tested two groups with the different degree of the market competition in the same year. We use the comparison of the DFVPS it coefficient absolute value to judge the value relevance of fair value information, and the greater the absolute value is, the higher relevance between the changes in fair value per share profits and losses with the stock prices, in order to test the hypothesis $\mathrm{H}$.

\begin{tabular}{|c|c|c|c|}
\hline Variable & Symbol & Variable name & Note \\
\hline $\begin{array}{c}\text { Dependent } \\
\text { variable }\end{array}$ & Pit & Share price & i company $\mathrm{t}+1$ year stock's closing price of the last \\
trading day of April*
\end{tabular}

*Note: Considering that most of the company's financial statements only disclose information need to April the following year or so, and investors in the disclosure of information can be based on financial statement information to make effective decisions, therefore, choose the last trading day of April the following year the stock's closing price as the dependent variable. Deng Chuanzhou (2005) also used the same approach.

Table 2. Variables defined table

\subsection{Sample Data}

Firstly, according to the above research of the market competition degree of the listed company in every industry, this paper regards the mining industry, the real estate industry, transportation and warehousing industry and the construction industry as the industry with low degree market competition. What's more, agriculture, forestry, animal husbandry, the fishery, manufacturing industry and social service industry is regarded as higher degree of industry competition. And according to the above 7 industries we select research sample in 2007 to 2011, nearly five years of the company, and remove the companies marked "ST", "SST" and other company whose data is not complete.

The data of the sample firms is from the CSMAR database and CCER database, and we use Excel and STATA to process the data.

\section{Descriptive Statistics and the Empirical Results Analysis}

\subsection{Descriptive Statistics}

In order to make the overall distribution of data more tend to standard normal distribution, so in addition to the variable DFVPSit (because there is so many zero in it), we generally use the method of logarithmic to process. 
Table 3 is the descriptive statistics for all samples. As can be seen from table 3,the mean of the profit and loss changes in fair value (DFVPS ${ }_{i t}$ ) is small and negative, the skewness coefficient is negative, which shows that company who use the fair value measurement are more tend to produce fair value loss, and it also can be seen from 0 median that most companies does not disclose gains and losses items in the changing of fair value, which may indicate that the use of fair value accounting measurement is not long in companies. Many companies are not clear whether they should disclosure the specific information of fair value, therefore they use the method of fair value measurement cautiously.

From the point of the standard deviation, the standard deviations of the two variables of stock price (P) and book value (BV) are large, with the stock price's standard deviation greater than 10, the book value's standard deviation greater than 2, which indicates that different company's stock price has a big difference, but compared with Table 4 we can conclude that the standard deviations of $\mathrm{P}$ and $\mathrm{BV}$ are less than 1 . What's more, the difference of stock price and book value in the same degree of competition is small, which can roughly explain that industry competition degree has a large influence on the company's share price and book value in China. The reason is that each company is influenced by the scope of the international financial crisis, and different industries are influenced by the financial crisis, leading to more investors pay attention to industry factors but not area factors.

\begin{tabular}{|c|c|c|c|c|c|c|}
\hline Variable & Mean & Median & S.D & Skewness & Kurtosis & Number \\
\hline Pit & 15.412 & 11.685 & 13.461 & 4.493 & 41.513 & \\
\hline BVit & 3.945 & 3.295 & 2.942 & 1.850 & 9.837 & 7032 \\
\hline Eit & 0.418 & 0.330 & 0.551 & 2.185 & 20.750 & \\
\hline DFVPSit & 0.0004 & 0 & 0.044 & -8.736 & 329.939 & \\
\hline
\end{tabular}

Table 3. Descriptive statistics (1)

In order to straightly observe the effect of the industry competition degree, table 4 lists the descriptive statistics of the two groups with different competition level. Among them, highly competitive industry are represented by the $\mathrm{HIGH}$, industry in low degree of competition are expressed in LOW. We can conclude that whatever the market competition degree is, the median and mean of fair price profits and losses per share close to 0 . China is strict in use of fair value which may be the reason. What's more, the application of the standards is strict too, all of this may make people more cautious when they use the fair value. The same result appear in table 4,the skewness of fair value gains and losses is far greater than 0 , the kurtosis is near 3, which shows that fair price profits and losses per share are difficult to suit for the standard normal distribution, and its valued is not uniform. 


\begin{tabular}{|c|c|c|c|c|c|c|c|}
\hline & iable & Mean & Median & S.D & Skewness & Kurtosis & Number \\
\hline \multirow{4}{*}{ High } & Pit & 2.493 & 2.431 & 0.585 & 0.774 & 3.804 & \multirow{4}{*}{4953} \\
\hline & BVit & 1.011 & 1.095 & 0.679 & -1.724 & 11.340 & \\
\hline & Eit & -1.404 & -1.171 & 1.172 & -0.598 & 3.190 & \\
\hline & DFVPSit & 0.003 & 0 & 0.043 & -2.4763 & 225.492 & \\
\hline \multirow{4}{*}{ Low } & Pit & 2.481 & 2.342 & 0.557 & 0.394 & 2.286 & \multirow{4}{*}{2070} \\
\hline & BVit & 1.043 & 1.030 & 0.614 & -0.188 & 3.339 & \\
\hline & Eit & -1.281 & -1.159 & 1.204 & -0.761 & 3.189 & \\
\hline & DFVPSit & 0.0013 & 0.001 & 0.040 & 1.012 & 10.480 & \\
\hline
\end{tabular}

Table 4. Descriptive statistics (2)

\subsection{The Regression Analysis of the Degree of Industry Competition}

Table 5 is the comparison of two groups with different industry competition degree in different year. By comparing the $R^{2}$ in different competition groups, we can find that the $R^{2}$ in higher industry competition is 0.1 larger than the lower industry competition degree, which means that it has increased about $10 \%$, and through the value of VIF there are no multi-collinearity. Except the variable changes in fair value gains and losses, $T$ value and $P$ value has significant correlation in the rest variables, net assets of per share and net income of per share have a strong explanation ability to stock price in the higher competition industry. Variables as net assets per share (BV) and net earnings per share (E) whose coefficients are significantly greater than 0 , show that the net assets per share and net income per share has a good positive explanatory ability on stock price, and the coefficient of net earnings per share is greater than the net assets per share, which further verify that "function lock of tables" phenomenon really exists in valuation by using accounting information. It is also to say that investors pay more attention to accounting income index than net asset information when they make investment decisions.

Except 2009, the absolute coefficients of fair value profit or loss per share (DFVPS it $_{\text {) }}$ in group HIGH is larger than that in group LOW, and the significant level gets a big improvement in 2010-2011, indicating that the degree of industry competition enhance the relationship between the changes of fair value profits and losses per share with stock price, namely that there is an increasingly value relevance in higher level competition market when we use the fair value information. At last, the hypothesis $(H)$ has been verified in a certain degree. 


\begin{tabular}{|c|c|c|c|c|c|c|c|c|c|c|}
\hline \multirow{2}{*}{$\begin{array}{c}\text { Year } \\
\text { Variable }\end{array}$} & \multicolumn{2}{|c|}{2007} & \multicolumn{2}{|c|}{2008} & \multicolumn{2}{|c|}{2009} & \multicolumn{2}{|c|}{2010} & \multicolumn{2}{|c|}{2011} \\
\hline & High & Low & High & Low & High & Low & High & Low & High & Low \\
\hline \multirow{2}{*}{ Cont. } & $6.94^{* * *}$ & $8.37^{* * *}$ & $5.37^{* * *}$ & 5.50 & $12.25^{* * *}$ & 2.64 & $8.47^{* * *}$ & $2.19^{* * *}$ & $5.17^{* * *}$ & 0.70 \\
\hline & -11.6 & -6.39 & -14.3 & -6.7 & -20.91 & -2.12 & -18.44 & -2.07 & -14.22 & -0.96 \\
\hline \multirow{3}{*}{ BVit } & $1.22^{* * *}$ & $0.62^{*}$ & $1.54^{* * *}$ & $1.00^{* * *}$ & 0.27 & $1.91^{* * *}$ & $1.10^{* * *}$ & $2.13^{* * *}$ & $0.78^{* * *}$ & $1.86^{* * *}$ \\
\hline & -6.49 & -1.62 & -12.24 & -3.94 & -1.51 & -5.93 & -10.56 & -7.86 & -9.45 & -10.22 \\
\hline & -1.48 & -1.51 & -1.7 & -1.36 & -1.67 & -1.34 & -1.73 & -1.57 & -1.68 & -1.47 \\
\hline \multirow{3}{*}{ Eit } & $11.6^{* * *}$ & $13.21^{* * *}$ & $5.55^{* * *}$ & $5.82^{* * *}$ & $14.83^{* * *}$ & $11.34^{* * *}$ & $13.53^{* * *}$ & $8.93^{* * *}$ & $10.15^{* * *}$ & $4.35^{* * *}$ \\
\hline & -17.39 & -7.56 & -13.36 & -6.77 & -18.05 & -6.46 & -19.52 & -5.83 & -24.16 & -4.74 \\
\hline & -1.5 & -1.53 & -1.7 & -1.32 & -1.67 & -1.35 & -1.72 & -1.56 & -1.67 & -1.48 \\
\hline \multirow{3}{*}{ DFVPSit } & $-16.6^{* *}$ & -15.48 & -6.44 & 3.34 & -5.58 & -20.79 & $-53.31^{* *}$ & $-43.21^{*}$ & $-18.92^{*}$ & $-15.62^{* *}$ \\
\hline & $(-2.22)$ & $(-0.42)$ & $(-1.43)$ & -0.83 & $(-0.33)$ & $(-1.31)$ & $(-2.44)$ & $(-1.70)$ & $(-1.51)$ & $(-2.13)$ \\
\hline & -1.02 & -1.02 & -1 & -1.05 & -1 & -1 & -1 & -1.01 & -1 & -1.01 \\
\hline Adj-R2 & 0.43 & 0.34 & 0.47 & 0.34 & 0.35 & 0.39 & 0.48 & 0.48 & 0.51 & 0.50 \\
\hline F-Value & 233.73 & 37.33 & 305.76 & 39.41 & 202.26 & 52.15 & 435.93 & 78.37 & 536.02 & 88.27 \\
\hline
\end{tabular}

Note: $*, * *, * * *$ represent significant under $10 \%, 5 \%, 1 \%$ respectively.

Table 5. Industry competition degree of regression analysis

It is worthy to notice that the coefficient of changes in fair value per share is negative, which means that the share changes in fair value gains and losses per share is greater and the price is lower. The phenomenon can be explained from the pro-cyclical effects of fair value under the background of financial crisis. Huang (2009) thinks that although the study of the pro-cyclical effects of fair value accounting is still in a primary stage, but most of scholars are of the view that fair value accounting has a cyclical effect. The performance of pro-cyclical effects brought by financial crisis allows financial institutions to confirm the massive losses, so that the deterioration of the economy has become more serious, and investors are weak in understanding information comprehension about fair value. Therefore, they are prone to procyclical effects of fair value. As the result, they will be pessimistic and willing to enlarge the market fluctuations, and then impact stock prices. The interpretation is similar to $\mathrm{Hu}$ and Liu (2012). they also think that investors will magnify any fluctuate the stock price in the market because of the situation of asymmetric information, which is "the herding effect" popularly existing in financial markets. Furthermore, the greater degree of competition in the industry, the easier to find the active or homogeneous market, so that using fair value measurement is easier. The investor's negative psychology reflected in stock price is that the larger the fair value information content, the more serious negative correlation among stock price. On the contrary, because the application environment of fair value in China is not perfect, it is easy to be interfered by other factors such as the lower degree of competition is, which means that the stronger the monopoly is, the more difficult to use of fair value. Because of the government intervention and the monopoly, some companies may avoid of the fair value procylicality. Hence investors tend to invest the company which enjoys the market protection and 
industrial protection, offsetting a portion of the negative effects brought by the fair value information.

\section{Conclusion}

The literature studies the degree of industry competition's impact on the value relevance of fair value information. We find that the higher the degree of competition in the industry, the more value relevance about fair value information. However, we also find fair value information often presents negative correlation with the stock price. A possible explanation is that because of the impact of the financial crisis, the pro-cyclical effects of fair value makes investors blindly after reading the financial data, and consider that the firm which use more fair value information will be higher risk and therefore affect their investment decision. This study argues that the value relevance of fair value information is vulnerable to the impact of the industry. At the present stage of China, we should guarantee the fair value accounting information exerting its decision usefulness through improving the company's external governance mechanism.

The policy implication of this study is:

1. Fair value is hierarchical and complex. The factors which affect the application of fair value accounting are complex and China need to promote the use of fair value accounting needs to be carried out step by step;

2. The characteristics of the level of competition is caused by regions and industrial differences in process of Chinese market-oriented reform, corporations in China need to gradually adapt to the tendency of expanding the application scope of fair value;

3. The value relevance of fair value information will be affected by the market environment. We need to consider the suitability of the application environment in order to improve the effect of the application of fair value accounting information.

Therefore, at the present stage of China, to guarantee the fair value accounting information exerting its decision usefulness, not only high quality fair value accounting standards should be developed and implemented, but also external governance mechanism should be improved. These two aspects are indispensable. Otherwise it cannot be achieved to improve the quality of fair value accounting information. 


\section{Acknowledgements}

The research work was supported by Humanities and Social Science Foundation of Guangdong (China) under Grant No. GD13CGL09.

\section{References}

Allen, F., \& Carletti, E. (2008). Mark-to-market accounting and liquidity pricing. Journal of Accounting and Economics, 45(2-3), 358-378. http://dx.doi.org/10.1016/j.jacceco.2007.02.005

Barth, M.E. (2004). Fair values and financial statement volatility. Cambridge: MIT Press.

Barth, M.E., \& Taylor, D. (2010). In defense of fair value: weighing the evidence on earnings management and asset securitizations. Journal of Accounting \& Economics, 49(1-2), 26-33. http://dx.doi.org/10.1016/j.jacceco.2009.10.001

Barth, M.E., Landsman, W.R., \& Wahlen, J.M. (1995). Fair value accounting: effects on banks' earnings volatility, regulatory capital, and value of contractual cash flows. Journal of Banking \& Finance, 19(3-4), 577-605. http://dx.doi.org/10.1016/0378-4266(94)00141-0

Boyer, R. (2007). Assessing the impact of fair value upon financial crises. Social Economic Review. Special issue: The socio-economics of accounting, 5(4), 779-807. http://dx.doi.org/10.1093/ser/mwm018

ECB (2004). Fair value accounting and financial stability. Occasional Paper Series, 13.

Feltham, G., \& Ohlson, J. (1995). Valuation and clean surplus accounting for operating and financial activities. Contemporary Accounting Research, 11(2), 689-731.

http://dx.doi.org/10.1111/j.1911-3846.1995.tb00462.x

Francis, J.R., Khurana, I.K., \& Pereira, R. (2003). The role of accounting and auditing incorporate governance and the development of financial markets around the world. Asian-Pacific Journal of Accounting and Economics, 10(1), 239-258.

http://dx.doi.org/10.1080/16081625.2003.10510613

Ge, J.S. (2009). Comment IASB/FASB joint conceptual framework that certain modifications, a progress of October 16, 2008 ended. Accounting Research, 4, 3-11.

Guillaume, P. (2009). Learning by holding and liquidity. Review of Economics Studies, 76(1), 395-412. http://dx.doi.org/10.1111/j.1467-937X.2008.00526.x

Guillaume, P., Sapra, H., \& Shin, H.S. (2008). Marking-to-market: Panacea or Pandoras' Box. Journal of Accounting Research, 46(2), 435-460. http://dx.doi.org/10.1111/j.1475-679x.2008.00281.x Haixia, G. (2011). Investor protection, product market competition and quality of information disclosure. MA. thesis. China: Xinjiang University of Finance and Economics. 
Hu, Y.M., \& Liu, Y.J. (2012). Fair value accounting and market volatility. Accounting Research, $6,12-18$.

Huang, S.Z. (2009). The pro-cyclical effect of fair value accounting and its countermeasures. Accounting Research, 11, 23-29.

Khan, U. (2008). Does fair value accounting contribute to systemic risk in the banking industry. Columbia Business School Research Paper.

Kothari, S.P, \& Zimmerman, J.L. (1995). Price and Return Models. Journal of Accounting and Economics, 20(2), 155-192. http://dx.doi.org/10.1016/0165-4101(95)00399-4

Laux, C., \& Leuz, C. (2009). The crisis of fair value accounting: Making sense of the recent debate. Accounting, Organization and Society, 34(6-7), 826-834.

http://dx.doi.org/10.1016/j.aos.2009.04.003

Li, Y.Q. (2011). Industry competition and the quality of accounting information-the evidence from Chinese Stock Market. Friends of Accounting, 13, 101-103.

Lu, X.Y. (2008). Under the new accounting standards system in China preliminary use of fair value. Modern Management Science, 4, 40-42.

Martin, S., \& Parker. D. (1997). Impact of privatization: Ownership and corporate performance in the United Kingdom. New York: Taylor and Francis Press.

http://dx.doi.org/10.4324/9780203439012

Nelson, K. (1996). Fair value accounting for commercial banks: An empirical analysis of SFAS107. The Accounting Review, 71(2), 161-182.

Wang, H.S. (2012). Investors legal protection, product market competition and the value of the company. Journal of Audit and Economics, 27(5), 57-66.

Wang, S.H., Sun, W.G., \& Li, Y. (2009). Fair value accounting and financial stability, analysis from the perspective of the financial crisis. Accounting Research, 10, 24-31.

Wallison, P. (2008). Fair value accounting: A Critique. www.aei.org

Yuan, M.Z. (2013). Empirical research on industry competition and enterprise accounting conservatism relations. Friends of Accounting, 33, 23-26.

Zhong, T.L., \& Fan, Y. (2004). The listed company product market competition and the selection of financial leverage. Accounting Research, 6, 29-33.

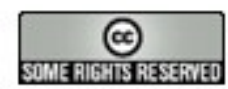

Article's contents are provided on a Attribution-Non Commercial 3.0 Creative commons license. Readers are allowed to copy, distribute and communicate article's contents, provided the author's and Journal of Industrial Engineering and Management's names are included. It must not be used for commercial purposes. To see the complete license contents, please visit http://creativecommons.org/licenses/by-nc/3.0/. 